\title{
Energy and Skeletal Muscle Protein Metabolism Balance and Weight Loss in Patients with Alzheimer's Disease: a Mini-Review
}

\author{
Tomiyo Nakamura*1 and Nobuko Amano ${ }^{2}$ \\ ${ }^{1}$ Department of Food Sciences and Human Nutrition, Faculty of Agriculture, Ryukoku University, Japan \\ ${ }^{2}$ Department of Clinical Nutrition and Dietetics, Faculty of Clinical Nutrition and Dietetics, Konan Women's University, Japan
}

Received: April 09, 2018; Published: April 17, 2018

*Corresponding author: Tomiyo Nakamura, Faculty of Agriculture, Ryukoku University, 1-5 Yokotani, Seta Oe-cho, Otsu, Shiga 520-2194, Japan

Keywords: Alzheimer's Disease; Weight Loss; Energy Expenditure; Energy Intake

\section{Introduction}

Weight loss is frequent in patients with Alzheimer's disease (AD), even in early disease stage [1]. Therefore, weight loss is a significant predictor of mortality in AD patients. The etiology of AD-associated weight loss is multifactorial, occurring when energy expenditure exceeds energy intake [2]. In addition, the loss of skeletal muscle protein, one of the causes of weight loss, occurs by an imbalance between the rate of protein synthesis and degradation [3]. Therefore, many studies have examined energy expenditure, energy intake, body composition, and other genetic factors in relation to weight loss in AD patients. This mini-review further discusses the factors leading to weight loss in AD patients.

\section{Energy Expenditure}

In the 1990s, higher energy expenditure was considered the possible cause of weight loss in $\mathrm{AD}$ patients. However, Donaldson et al. [4] reported that resting metabolic rate was not significantly different between AD patients and controls. Poehlman et al. [5] revealed that daily energy expenditure was $14 \%$ lower in $\mathrm{AD}$ patients compared to controls. In a recent study, Venturell et al. [6] also showed that $\mathrm{AD}$ patients and controls have similar levels of daily expenditure. Therefore, it can be inferred that $\mathrm{AD}$ patients do not have disease-specific higher energy expenditure.

\section{Energy Intake}

Patients with $\mathrm{AD}$ have many eating problems, such as swallowing or chewing difficulties, a refusal to eat or drink, suspected dehydration, and persistently reduced oral intake [7]. Impaired swallowing function appears as the disease progresses, resulting in aspiration pneumonia in late-stage disease; texturemodified diets (TMD) are used to prevent this [8]. TMD has been shown to comprise lower energy-, and protein content than normal diets, and can lead to malnutrition [9]. According to Olin et al., higher energy density hospital food can prevent weight loss in patients with dementia [10].

\section{Body Composition}

Aging changes body composition in elderly patients [11] due to Sarcopenia. Burns et al. [12] showed that lean body mass was reduced in patients with early $\mathrm{AD}$ compared to controls, however, total body fat and percent body fat were not different between two groups. With aging, anabolic hormones such as testosterone, estrogen or growth hormone (ex. IGF-I) are decreased, and catabolic hormones (ex. cortisol) and inflammatory cytokines (ex. TNF-alpha) are increased. Burns et al. [12,13] suggested that the loss of lean body mass shared mechanisms common to both AD and Sarcopenia, which are accelerated in $\mathrm{AD}$, and related to brain atrophy and cognitive performance. Venturelli et al. [7] reported that serum albumin was significantly reduced in $\mathrm{AD}$ patients, and Visser et al. [14] showed that low serum albumin concentration might be a risk factor for Sarcopenia. Therefore, Sarcopenia was considered to occur due to multiple factors such as malnutrition, inactivity, cognitive function in $\mathrm{AD}$ patients.

\section{Conclusion}

Weight loss in $\mathrm{AD}$ patients is multifactorial, caused by a disorder of energy and skeletal muscle protein metabolism balance. 
To prevent weight loss in $\mathrm{AD}$ patients, nutritional care and support, and therapy for activity-related Sarcopenia are necessary.

\section{References}

1. Stewart R, Masaki K, Xue QL, Peila R, Petrovitch H, et al. (2005) A 32-year prospective study of change in body weight and incident dementia: the Honolulu-Asia Aging Study. Arch Neurol 62(1): 55-60.

2. White H, Pieper C, Schmader K (1998) The associations of weight change in Alzheimer's disease with severity of disease and mortality: a longitudinal analysis. J Am Geriatr Soc 46(10): 1223-1227.

3. Gillette-Guyonnet S, Secher M, Vellas B (2013) Nutrition and neurodegeneration: epidemiological evidence and challenges for future research. Br J Clin Pharmacol 75(3): 738-755.

4. Evans WJ (2010) Skeletal muscle loss: cachexia, sarcopenia, and inactivity. Am J Clin Nutr 91(4): 1123S-1127S.

5. Donaldson KE, Carpenter WH, Toth MJ, Goran MI, Newhouse P, et al.(1996) No evidence for a higher resting metabolic rate in noninstitutionalized Alzheimer's disease patients. J Am Geriatr Soc 44(10): 1232-1234.

6. Poehlman ET, Toth MJ, Goran MI, Carpenter WH, Newhouse P, et al (1997) Daily energy expenditure in free-living non-institutionalized Alzheimer's patients: a doubly labeled water study. Neurology 48(4): 997-1002.

7. Venturelli M, Cè E, Limonta E, Muti E, Scarsini R, et al. (2016) Possible Predictors of Involuntary Weight Loss in Patients with Alzheimer's Disease. PLoS One 11(6): e0157384.

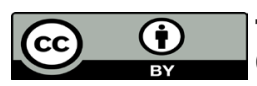

This work is licensed under Creative Commons Attribution 4.0 License

Submission Link: https://biomedres.us/submit-manuscript.php
8. Mitchell SL, Teno JM, Kiely DK, Shaffer ML, Jones RN, et al. (2009) The clinical course of advanced dementia. N Engl J Med 361(16): 1529-1538.

9. Austbø Holteng LB, Frøiland CT, Corbett A (2017) Care staff perspective on use of texture modified food in care home residents with dysphagia and dementia. Ann Palliat Med 6(4): 310-318.

10. Olin AO, Osterberg P, Hådell K, Armyr I, Jerström S, et al. (1996) Energyenriched hospital food to improve energy intake in elderly patients. JPEN J Parenter Enteral Nutr 20(2): 93-97.

11. St-Onge MP, Gallagher D (2010) Body composition changes with aging: the cause or the result of alterations in metabolic rate and macronutrient oxidation? Nutrition 26(2): 152-155.

12. Burns JM, Johnson DK, Watts A, Swerdlow RH, Brooks WM (2010) Reduced lean mass in early Alzheimer disease and its association with brain atrophy. Arch Neurol 67(4): 428-433.

13. Cruz-Jentoft AJ, Baeyens JP, Bauer JM, Boirie Y, Cederholm T, et al. (2010) Sarcopenia: European consensus on definition and diagnosis: Report of the European Working Group on Sarcopenia in Older People. Age Ageing 39(4): 412-423.

14. Visser M, Kritchevsky SB, Newman AB, Goodpaster BH, Tylavsky FA, et al. (2005) Lower serum albumin concentration and change in muscle mass: the Health, Aging and Body Composition Study. Am J Clin Nutr 82(3): 531-537.

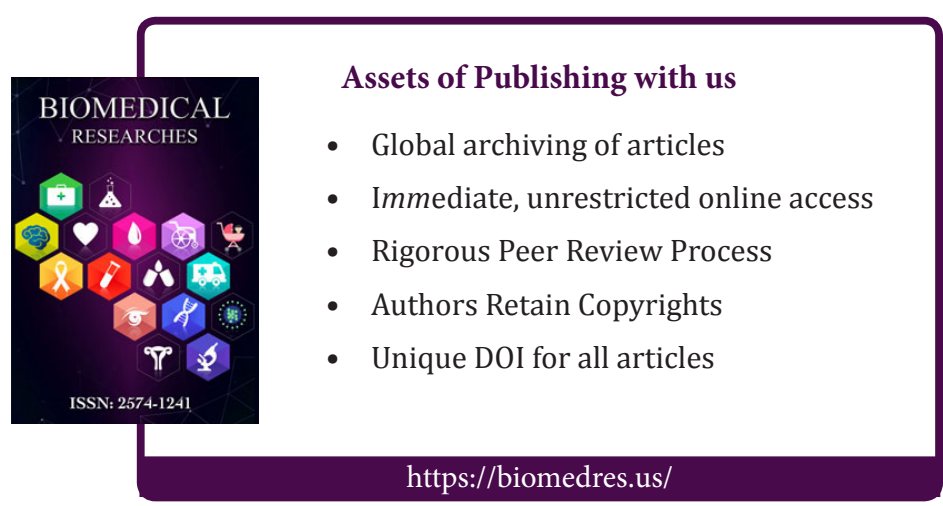

